Relations industrielles

Industrial Relations

\title{
Puette, William J., Through Jaundiced Eyes : How the Media View Organized Labor
}

\section{Anil Verma}

Volume 49, numéro 1, 1994

URI : https://id.erudit.org/iderudit/050932ar

DOI : https://doi.org/10.7202/050932ar

Aller au sommaire du numéro

Éditeur(s)

Département des relations industrielles de l'Université Laval

ISSN

0034-379X (imprimé)

1703-8138 (numérique)

Découvrir la revue

Citer ce compte rendu

Verma, A. (1994). Compte rendu de [Puette, William J., Through Jaundiced Eyes :

How the Media View Organized Labor]. Relations industrielles / Industrial

Relations, 49(1), 205-206. https://doi.org/10.7202/050932ar

Tous droits réservés (C) Département des relations industrielles de l'Université Laval, 1994
Ce document est protégé par la loi sur le droit d'auteur. L'utilisation des services d'Érudit (y compris la reproduction) est assujettie à sa politique d'utilisation que vous pouvez consulter en ligne.

https://apropos.erudit.org/fr/usagers/politique-dutilisation/ 
In summary, the second edition of Aggarwal's book is a worthwhile addition to any human resource professional's library.

P. ANDiappan

University of Windsor

Through Jaundiced Eyes : How the Media View Organized Labor, by William J. PueTTE, Ithaca, NY, ILR Press, 1992, 228 p., ISBN 0-87546-185-9

This well-researched book on media's treatment and portrayal of labour is both timely and useful. The importance of mass media as a sometimes silent, sometimes noisy player in the industrial relations system has grown over the years. Yet, formal analysis of its role in the system has not received the scruitiny that its growing importance suggests.

Puette focuses on media's treatment of labour rather than on media's role in the industrial relations system as a whole. He asks both the pertinent questions: is there a bias in the media against labour and, if yes, what may be the underlying causes? The first question comes out of a long research tradition which goes back to radio broadcasts of the 1920s. There is general agreement among most studies that media is prone to distortions, whether intended or not, that are unfavourable to labour interests.

What distinguishes this book from others in answering the question of bias is its comprehensive treatment of several forms of mass media. Chapter One deals with movies, Chapter Two with television news, Chapter Three with television dramas, Chapter Four with newspapers, and Chapter Five with cartoons. Chapters Six and Seven present two in-depth case studies on specific labour events covered by the media. The first case is that of a dispute between a Maui construction contractor and the Carpenters Union. Newspaper reports taken from three Hawaii newspapers between 1983 and 1986 form the basis for this part of the analysis. The second case is that of the Mine Workers' strike against the Pittston Company in 1989-90. Chapter Eight deals with labour's response to this bias. Chapter Nine, the last Chapter, provides a summary and an analytical synthesis.

Apart from the main chapters, the book also offers a rich database for researchers in the appendices. Appendix B provides a detailed list of American movies in which labour was a major theme. Appendix $C$ similarly provides a list of TV network news specials and TV documentaries about labour unions. Appendix D contains plot synopses of TV dramas.

In each chapter, themes, dialogues, musings, and commentaries that appear ordinary to the lay eye, are carefully deconstructed for their impact on labour's image and interests. Puette uses Cirino's (1971) "catalogue of hidden bias" as a guide for this analysis. Cirino's work was aimed at discovering media bias in general which is cleverly adapted to the question of bias against labour. Another analytical technique used in the book is Parenti's (1986) seven basic generalizations that typify medias treatment of labour. These analytical frameworks are used to examine each form of mass media. 
Puette's main findings are similar to and corroborative of previous studies on the subject (see Verma (1988) for a Canadian study). He finds a pervasive bias against labour in all forms of media. He offers a set of eight "lenses" that, he finds, colour media's treatment of labour. These perceptions go beyond Parenti's seven "generalizations" which were confined mostly to the issue of strikes. Puette's thesis is that the misperceptions captured by the eight lenses have been absorbed so throroughly into the conception of labour and labour relations by the media that the resulting portrayal of organized labour will always be guided by negative stereotypes.

This book is at its thinnest when it comes to finding the root causes of bias and to the question of what can be done about it. Chapter eight very briefly considers some explanations. For example, "to the average American, .... organized labor is a distant but recurrent phenomenon". At another place, the author speculates that "newspapers encourage rotation rather than stability of their labour beat". He also explores the liberal slant of American media who have been accused of being "left-leaning" but have proved to be conservative when it comes to perceptions of labour.

Chapter Eight will be of interest to those who want to do something about it. It considers two of labour's responses to this bias: monitoring the media to make the journalists aware of the biases and advocacy advertising. The most definitive work in this area is a study by Douglas (1986) who documented labour's effective use of the media to protect its interests especially during an organizing drive. The book offers little by way of an action agenda except to endorse previously employed tactics and media advertising like the AFL-CIO "UNION, YES!" campaign. Such campaigns might improve labour's image with the public but whether they can improve media's perceptions is not explicitly addressed.

Puette's book is a must read for anyone interested in the media's relationship with industrial and labour relations. Given the paucity of recent studies in this area, this book is a welcome addition to the literature and a useful resource for all researchers interested in labour.

Anil Verma

University of Toronto 